\title{
Experiment-based Study on the Impact of Soiling on PV System's Performance
}

\author{
Wan Juzaili Jamil ${ }^{1,2}$, Hasimah Abdul Rahman ${ }^{1,2}$, Kyairul Azmi Baharin ${ }^{1,2}$ \\ ${ }^{1}$ Centre of Electrical Energy Systems (CEES), Institute of Future Energy, Universiti Teknologi Malaysia (UTM), 81310 \\ Johor Bahru, Johor, Malaysia \\ ${ }^{2}$ Centre of Electrical Energy Systems (CEES), Fakulti Kejuruteraan Elektrik, Universiti Teknologi Malaysia (UTM), \\ 81310 Johor Bahru, Johor, Malaysia
}

\begin{tabular}{|c|c|}
\hline Article Info & ABSTRACT \\
\hline Article history: & Soiling refers to the accumulation of dust on PV modules which plays a \\
\hline Received Oct 11, 2015 & $\begin{array}{l}\text { small but significant role in degrading solar photovoltaics system efficiency. } \\
\text { Its effect cannot be generalized because the severity is location and }\end{array}$ \\
\hline Revised Dec 13, 2015 & environment dependent. Currently, there are limited studies available on the \\
\hline Accepted Jan 3, 2016 & $\begin{array}{l}\text { soiling effect in the hot and humid Malaysian tropical climate. This paper } \\
\text { presents an experimental-based approach to investigate the effect of soiling }\end{array}$ \\
\hline Keyword: & $\begin{array}{l}\text { on PV module performance in a tropical climate. The experiment involved a } \\
\text { full day exposure of a polycrystalline PV module in the outdoors with }\end{array}$ \\
\hline $\begin{array}{l}\text { Dust } \\
\text { Performance }\end{array}$ & $\begin{array}{l}\text { accelerated artificial dust loading and an indoor experiment for testing } \\
\text { variable dust dimensions. The findings show that for the worst case, the } \\
\text { module's output can be reduced by as much as } 20 \% \text {. }\end{array}$ \\
\hline
\end{tabular}

Copyright (C) 2016 Institute of Advanced Engineering and Science. All rights reserved.

\section{Corresponding Author:}

Hasimah Abdul Rahman,

Centre of Electrical Energy Systems (CEES), Institute of Future Energy,

Universiti Teknologi Malaysia (UTM),

81310 Johor Bahru, Johor, Malaysia.

Phone: +607-555 7002/7006, Fax: +607-555 7005

Email: hashimahar@utm.my

\section{INTRODUCTION}

PV systems generate electricity via the conversion of sunlight irradiation. Thus, the PV modules need to be mounted outdoor where maximum sunlight can be obtained [1]. Nonetheless, by exposing the modules outdoor, the module's surface will be easily accumulated with the presence of dust; or worse, without a prior cleaning scheme in a long duration, leading to vegetation of lichens. This kind of accumulation will prevent the sunlight from directly reaching the module's surface. Meanwhile, other external factors such as the fluctuation of global solar irradiance, ambient temperature, humidity, wind velocity, site characteristic (local vegetation, pedestrian and vehicular traffic, air pollution, etc.) will also contribute to the performance degradation of the PV system [2, 3]. According to several researches, the issue of soiling or dust can become serious, depending to their site environmental condition, PV system's scale and the financial consideration [4-7]. Not only that, generally, conventional PV module only convert $4-17 \%$ of the received irradiation into electricity [8]. Thus, the effect of soiling will worsen the efficiency of PV system. This situation becomes a further challenge in achieving the common purpose of PV system installation, which already face challenges to minimize the system's cost, minimize the system's performance loss over time and finally to maximize the systems' output or benefit [9]. On the other perspective, there are limited studies on investigating the soiling effect upon PV system in the hot and humid Malaysian tropical climate [10]. 


\section{BACKGROUND OF STUDY}

Soiling is formed from the accumulation of dust over a surface, in this case the surface of PV modules. Sometimes it may come from the deposition of dirt like bird dropping or splatted mud which is referred as cemented soiling. Generally, the term dust is often used to describethe soiling issue. According to Mekhilef et al, dust is one of the three factors identified from nature besides humidity and air velocity which may affect PV systems performance [3]. Mani and Pillai defined that dust is a term generally applied to minute solid particles with diameters less than 500 $\mu \mathrm{m}$ [2]. They also developed a framework indicating the factors influencing dust settlement as in the Figure 1.

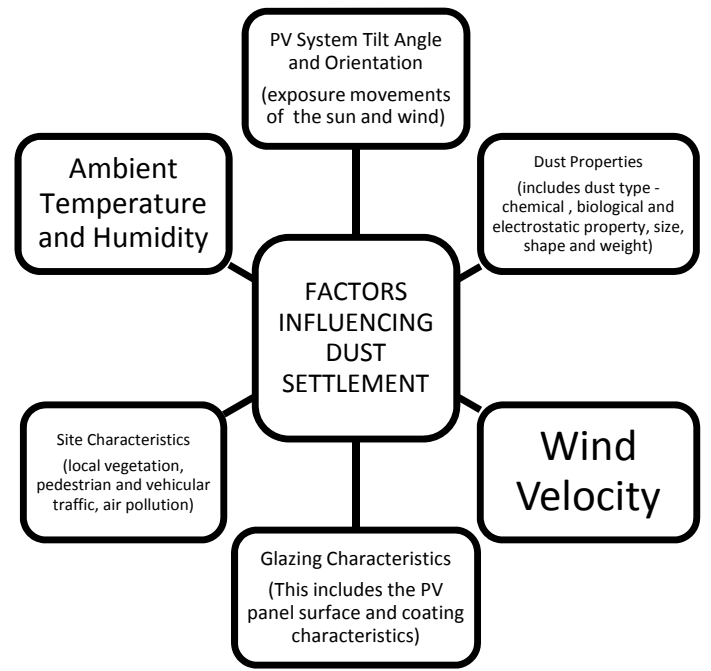

Figure 1. Factors influencing dust settlement by Mani and Pillai in 2010 [2]

Referring to Figure 1, dust comes in various characteristic and can be analysed at different property such as chemical property, biological property, electrostatic property and physical property (size, shape and weight). Soiling comprised a varying composition of different dust types together because it is transported by wind (mostly) from the different origins (depending on the wind direction) before settling down on any kind of surface. Local site activity determines the dust settlement rate in the specific area such as air pollution [11], nearby industry, nearby construction site [12], transportation facility [13] and nature act (volcanic eruption, haze from forest burning, sandstorm, etc.) In addition to that, wind can be considered as one of the major factors contributes to the soiling problem apart from ambient temperature and relative humidity.

Mani and Pillai's framework also identified that other than the geographical factors and dust property, the module surface's morphology and the way it's being mounted (exposure to the atmosphere and tilt angle) can also influence the soiling rate [14-16].

Previous studies have discovered the effect of soiling can reduce the PV system's performance (efficiency, output power and I-V curve characteristic) [4-6, 17-21]. However, most of them come up with different results and justifications on the impact of soiling to PV system's performance due to the different geographical condition on the studied site. In Malaysia, the result might be different. This paper somehow is addressing the soiling issue in the hot and humid Malaysian tropical climate based on two set of experiments. The first one was conducted outdoor while the other one was performed in the laboratory. The result from the laboratory experiment was compared with the at least similar study by Sulaiman et al, 2014 for validation.

\section{PROBLEM STATEMENT}

Soiling plays a small but significant role in decreasing PV power output. Its severity is highly dependent on the installation location. PV systems near deserts and beaches are subject to higher amount of soiling, as for systems in a polluted environment. Another factor is the dimension of soiling elements. The dirt may consist of desert dust, airborne pollutants, bird droppings or other particulate molecules which vary in shape and size. Studies on the impact of soiling on PV modules are limited, especially for tropical climate countries such as Malaysia. This research attempts to fill the gap using experimental-based analysis on the soiling effect. 


\section{METHODS}

Two experiments have been conducted. The first experiment involved the single day exposure of a $10 \mathrm{~W}$ rated polycrystalline PV module in the atmospheric condition with the accelerated artificial dust loading. The dimensions of the PV module were $350 \mathrm{~mm}$ (width) by $300 \mathrm{~mm}$ (length) by $17 \mathrm{~mm}$ (thickness). Wheat flour (in gram per meter ${ }^{2}$ ) was used as artificial dust and being deposited evenly on the module surface every half an hour, then the output (module $V_{o c}$ and module $I_{s c}$ ) were observed. For every measurement taken of $V_{o c}$ and $I_{s c}$, the possible natural parameters in relation to the PV module performance along with influence of dust settlement which are solar irradiance, ambient temperature, relative humidity $(\mathrm{RH})$ and wind speed were recorded. The experiment was conducted in day from morning to evening. The measurement taken is shown in Figure 2 to Figure 6.

Figure 2 indicates the irradiance level measured during the outdoor experiment together with the accelerated dust loading. However, it does not resemble the important findings related to dust effect as both parameters here are independence. They are only measured to be as a reference. Usually, in the atmospheric condition, dry weather with high irradiance may accelerate the dust settlement rate. Dusts can easily being blown by wind when it dries. It is also observed that the rapid fluctuations of the irradiance value during the measurement. This happens because of the unpredictable weather condition on that day. It was raining heavily between 3.00 p.m. to 4.30 p.m. and the cloud formation was changing promptly in the sky.

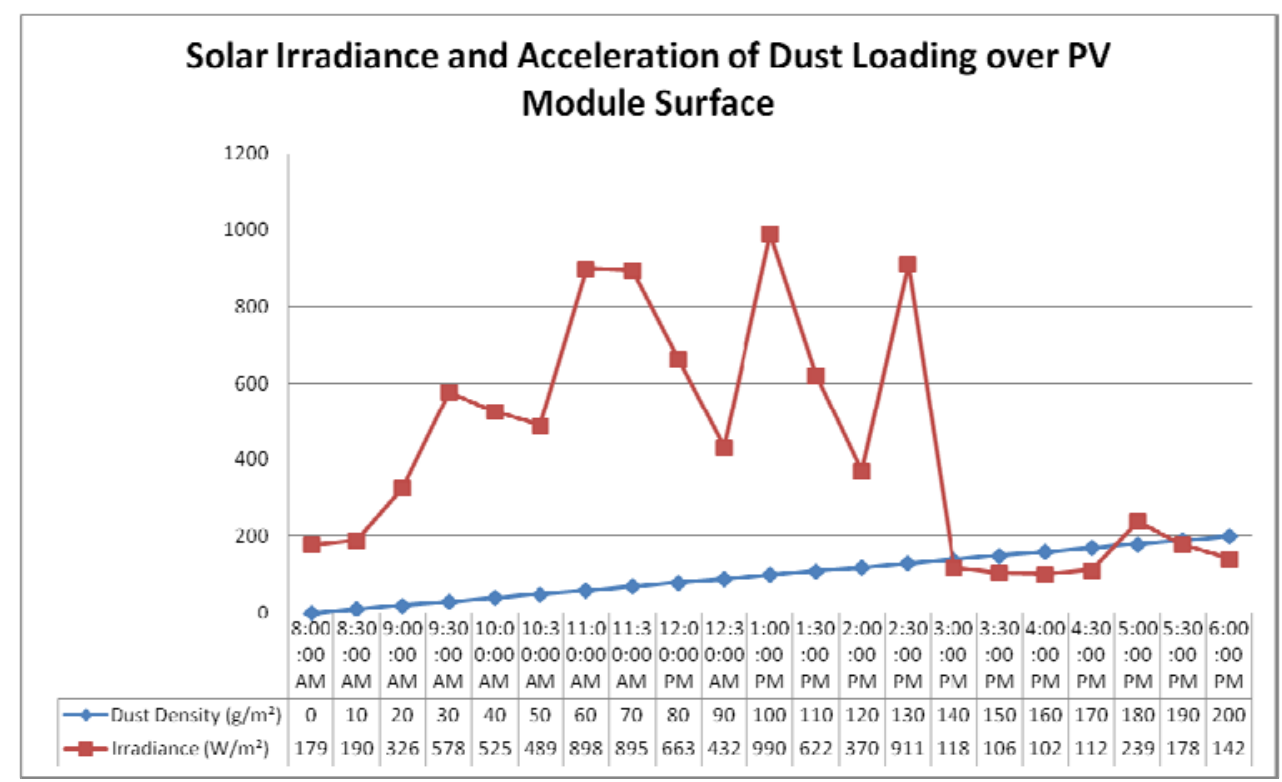

Figure 2. Solar irradiance trend in single day with the accelerated artificial dust loading

The behavioral of climatic and meteorological conditions are illustrated in Figure 3 and Figure 4. They show the correlation between ambient temperature, relative humidity and windspeed to irradiance level. It can be observed in Figure 3 that the ambient temperature is low in the morning due to low solar irradiance level, so less heat been transferred to atmosphere. Also, the ambient condition will get hotter as the sun rising and decreasing by the end of the day. Additionally, during rain or cloudy weather, where the irradiance level is low, the ambient temperature will decrease accordingly to the available heat in the atmosphere. Meanwhile, for $\mathrm{RH}$, it is reduced during warm condition (refer Figure 3). When the surrounding getting warmer, the ambient temperature will rise, water vapors easily evaporate in the air, leave the condition drier.

For a typical wind speed characteristic as in Figure4 shows that it usually independent and do not totally rely on solar irradiance, ambient temperature and relative humidity. The pattern of wind speed in a single day is unpredictable and intermittent. It may increase in the dry condition, low ambient temperature, or even during raining. From metrological study, wind speed is governed by the orbital movement of the moon which also determine the ebb and flow of seawater level. 


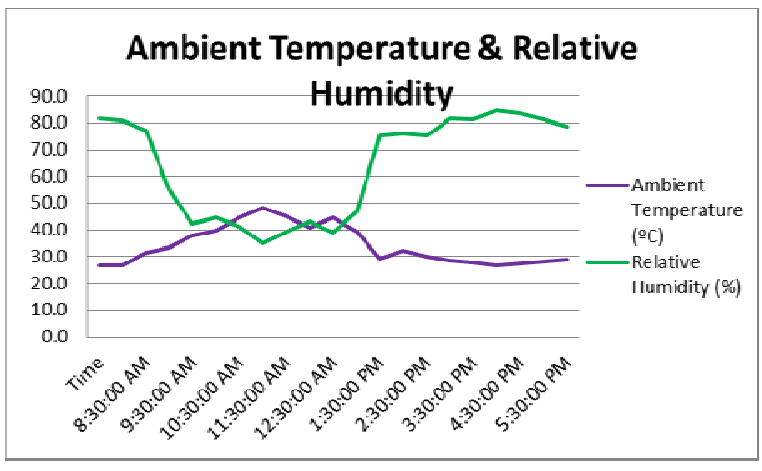

Figure 3. A typical ambient temperature and RH profile

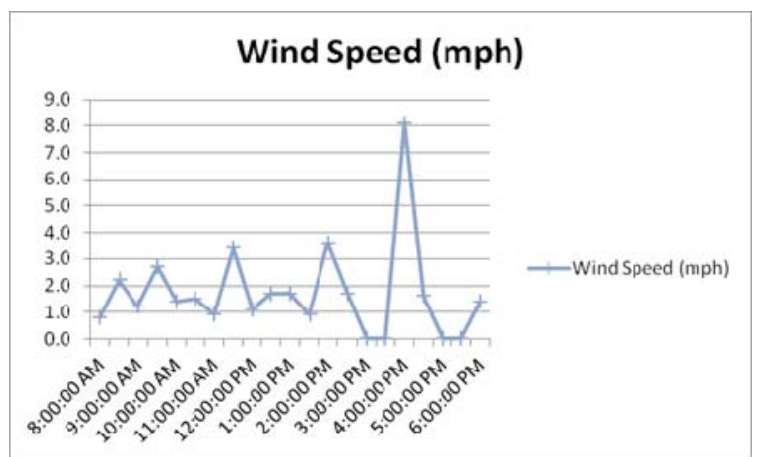

Figure 4.A typical wind speed profile

The module outputs which are $V_{o c}$ and $I_{s c}$ supposed to be the dependence variables of dust settlement, solar irradiance, ambient temperature, $\mathrm{RH}$ and wind speed. The correlation is significant when compares to the irradiation pattern, $V_{o c}$ and $I_{s c}$. However, Figure 5 and Figure 6 illustrate both $V_{o c}$ and $I_{s c}$ have similar trend curve as the solar irradiance respectively. These values degrade in the end of the day due to the low irradiation and proliferation of dust density. During the highest irradiance level of $990 \mathrm{~W} / \mathrm{m}^{2}$ and the dust accumulation is $100 \mathrm{~g} / \mathrm{m}^{2}, V_{o c}$ is measured at $18.99 \mathrm{~V}$ and $I_{s c}$ is at $1.62 \mathrm{~A}$. At lowest irradiance of 102 $\mathrm{W} / \mathrm{m}^{2}$, the dust accumulation is $160 \mathrm{~g} / \mathrm{m}^{2}$, the values of $V_{o c}$ and $I_{s c}$ are measured at $4.80 \mathrm{~V}$ and $0.30 \mathrm{~A}$ respectively. The results are tabulated in Table 1.

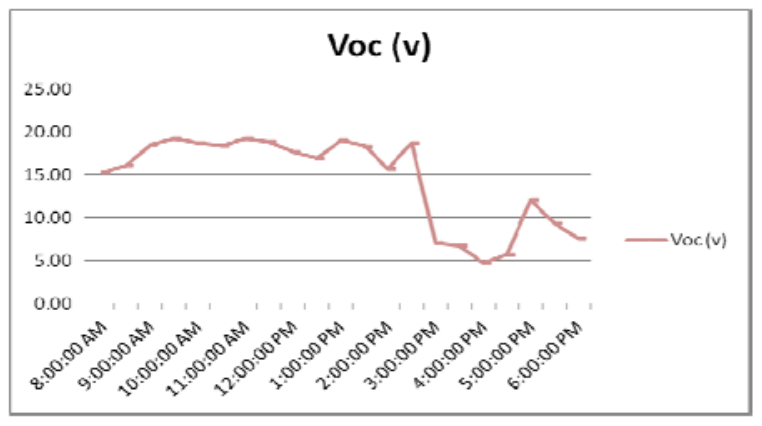

Figure 5. Module $V_{o c}$ with accelerated soiling

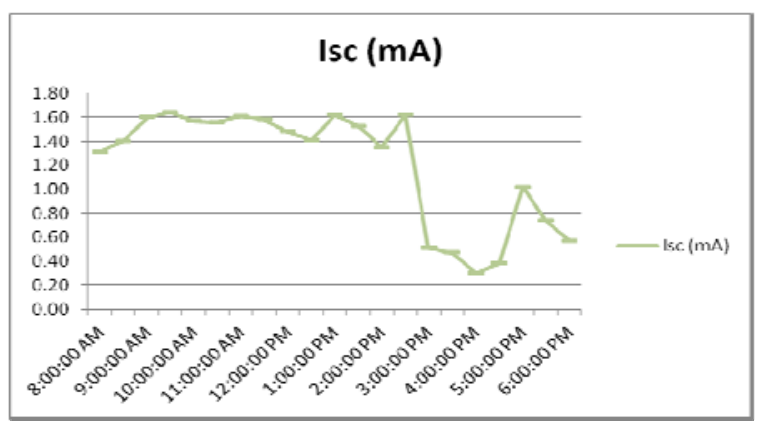

Figure 6. Module $I_{s c}$ with accelerated soiling

Table 1. A typical day outdoor experimental results

\begin{tabular}{cccc}
\hline Irradiance & Dust Density $\left(\mathrm{g} / \mathrm{m}^{2}\right)$ & $\boldsymbol{V}_{\boldsymbol{o c}}(\mathrm{V})$ & $\boldsymbol{I}_{\boldsymbol{s c}}(\mathrm{A})$ \\
\hline 990 & 100 & 18.99 & 1.62 \\
104 & 160 & 4.80 & 0.30 \\
$89.49 \%$ reduction & $40 \%$ increment & $74.72 \%$ reduction & $81.48 \%$ reduction \\
\hline
\end{tabular}

It can be observed that the values of $V_{o c}$ and $I_{s c}$ is reduced significantly according to the low level of irradiance and with the increased of dust density. This result is true for $I_{s c}$ alternatively not for $V_{o c}$ where theoretically it is not true because $V_{o c}$ never follow the irradiation pattern. It is possible that the heating from the irradiation caused the reduction in its value.

An indoor experiment was conducted by using the same module and artificial dust. This experiment is actually to verify the outdoor experiment findings. In this experiment a $500 \mathrm{~W}$ spotlight is used as an artificial solar source and a closed laboratory room at ambient temperature of $25{ }^{\circ} \mathrm{C}$. Before performing the experiment, the irradiance levels and light intensity from the spotlight which is hang over the module need to be measured. They were measured at nine different points due to irregularity of light dispersion. The average value calculated from the nine points are $396.2222 \mathrm{~W} / \mathrm{m}^{2}$ and 1395.7778 lux each's. 
The experiment set up is as shown in Figure 7in a dark laboratory. The spotlight was used instead of natural sunlight to maintain the irradiance level while observing the increment of dust density (in gram per meter $^{2}$ ) effect to the $V_{o c}$ and $I_{s c}$. The PV module was placed horizontally facing the spotlight. The soiling test was conducted by loading the wheat flour on the module surface with its density being increased by $10 \mathrm{~g} / \mathrm{m}^{2}$ for each measurement. At the same time, the variation of $V_{o c}$ and $I_{s c}$ were recorded.

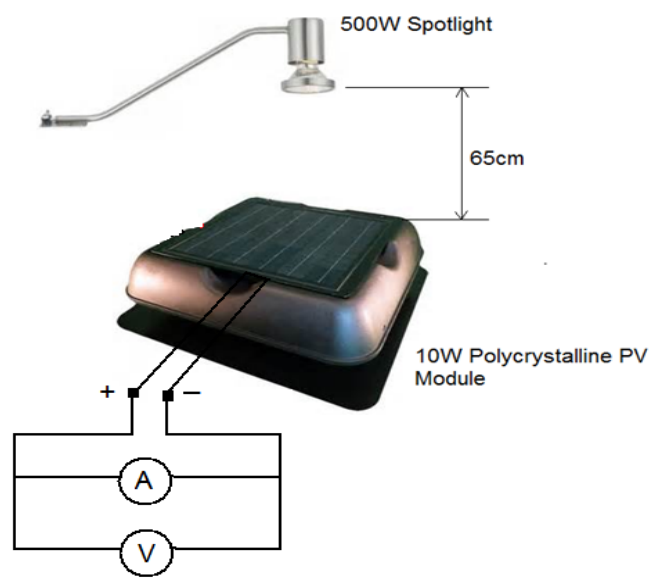

Figure 7. The experimental setup

\section{RESULTS AND DISCUSSION}

In the first experiment where the artificial soiling rate being accelerated in the atmospheric condition, the module outputs, $V_{o c}$ and $I_{s c}$ responded accordingly to the solar irradiance level. Whenever the irradiance level is low, the outputs generated are also low and when the irradiance level is high, the output will rise. But, the output may not resemble the total response because of the presence of dust over the panel which increases rapidly along the measurement. This can be seen through the graphs in Figure 8 and Figure 9.

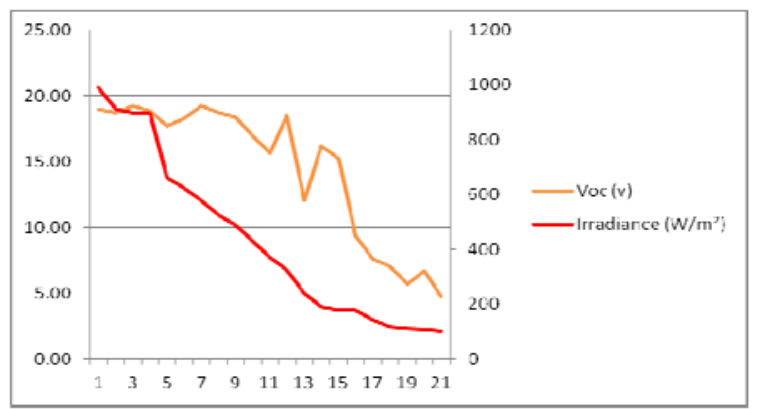

Figure 8. Module $V_{o c}$ with accelerated soiling

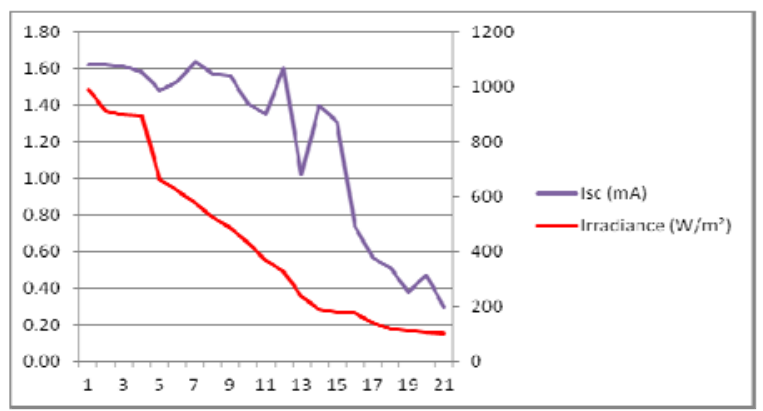

Figure 9. Module $I_{s c}$ with accelerated soiling

This result can only show the PV module output pattern due to the accelerated soiling in single day. There is nothing much can be justified from the experiment in relation to the impact of soiling and PV system's performance. The experiment need to be performed in much longer period to come out with conclusive findings. Furthermore, the fluctuation of the solar irradiance (supposed to be the fixed parameter) during the measurement due to some natural influences such as cloud formation (depending on wind speed and wind direction) and RH (depending on ambient temperature) [22], it is hard to analyze the module output variation on the reduce irradiation due to the accelerated soiling. This will complicate the soiling effect study. Not to forget, the heat absorbed by the module from ambient and solar irradiance might also reduce the performance [23].

Malaysia is different from other country. It is located in the equator which experiencing hot and humid climate at the same time. Most of the period, the cloud formation is difficult to be predicted. Plus, in here, there is no obvious dry season and wet season which soiling quantification is easily being made.

Experiment-based Study on the Impact of Soiling on PV System's Performance (Hasimah Abdul Rahman) 
Usually, soiling phenomenon on PV module surface was studied in a stable dry season and mostly in the country which have this type of climate [24-26]. Therefore, the second experiment was performed in laboratory with the controlled situation to study the same soiling acceleration but with fixed irradiation and surrounding temperature.

The second experiment showed that with the increment of the artificial dust density, the $V_{o c}$ and $I_{s c}$ were reduced. The correlation of dust density and the module $V_{o c}$ is shown in Figure 10. It was observed that $V_{o c}$ slightly reduced from 18.99 to $15.31 \mathrm{~V}$ (20.01\% decrement) with the proliferation of the dust density from 0 to $200 \mathrm{~g} / \mathrm{m}^{2}$. According to the common semiconductor fundamental, $V_{o c}$ should be less affected by the irradiance but should respond to the module temperature. However, in this experiment, $V_{o c}$ might have also been reduced by the rise of module temperature due to the short distance $(65 \mathrm{~cm})$ of module surface from the spotlight.

The effect of artificial dust to the $I_{s c}$ is presented in Figure 11. Similar with $V_{o c}$, it was seen that $I_{s c}$ also slightly reduced from $1.64 \mathrm{~mA}$ to $1.31 \mathrm{~mA}$ (20.12\% reduction). The result obtained was gained through the increment of artificial dust loading until $200 \mathrm{~g} / \mathrm{m}^{2}$. Both of $V_{o c}$ and $I_{s c}$ were expected to decrease more if the loading had been prolonged.

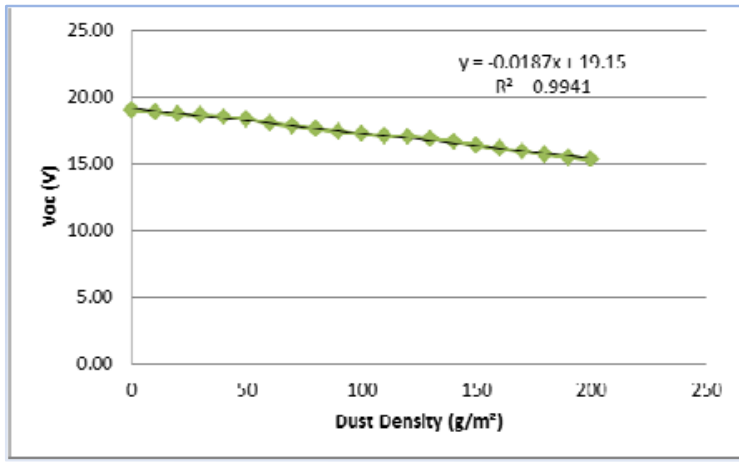

Figure 10. The reduction of $V_{o c}$

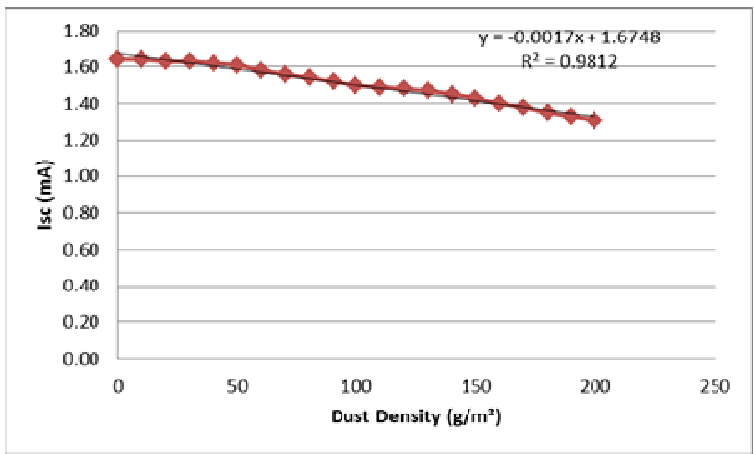

Figure 11. The reduction of $I_{s c}$

Result obtained from the second experiment was compared with finding from Sulaiman et al 2014 works [10]. The study by this group conducted a set of laboratory experiment to study the effect of dirt on a PV module's output. Although the approach taken is quite different, their study is the most similar work which can be compared to here. Differently from this study, their works investigate the effect of various dirts on the PV module's output like talcum, dust, sand, water droplet and a layer of vegetated moss which were spread evenly on the module surface. However, in here, the wheat flour loading on the module surface was measured in gram per meter square which is more accurate than the average spreading. Besides, their study observing the module's output power reduction which was done by connecting the module to small loads like bulbs and motor with the different light irradiance input. This was not done in this study, the module output was measured on the no load condition.

Comparison can be made by observing the depletion of $V_{o c}$ and $I_{s c}$ with the I-V curved plotted fromSulaiman et al 2014 works as in Figure 12. At the average irradiance of $250 \mathrm{~W} / \mathrm{m}^{2}$, it can be estimated that the reduction of $V_{o c}$ and $I_{s c}$ for talcum only (which is similar to wheat flour physical texture) are about $2.24 \%$ and $13.46 \%$ each. While at the average irradiance of $350 \mathrm{~W} / \mathrm{m}^{2}$, the values are $2.91 \%$ and $18.31 \%$ each. Table 2 below the figure shows the comparison of the indoor experiment conducted and the one obtained by Sulaiman et al. 

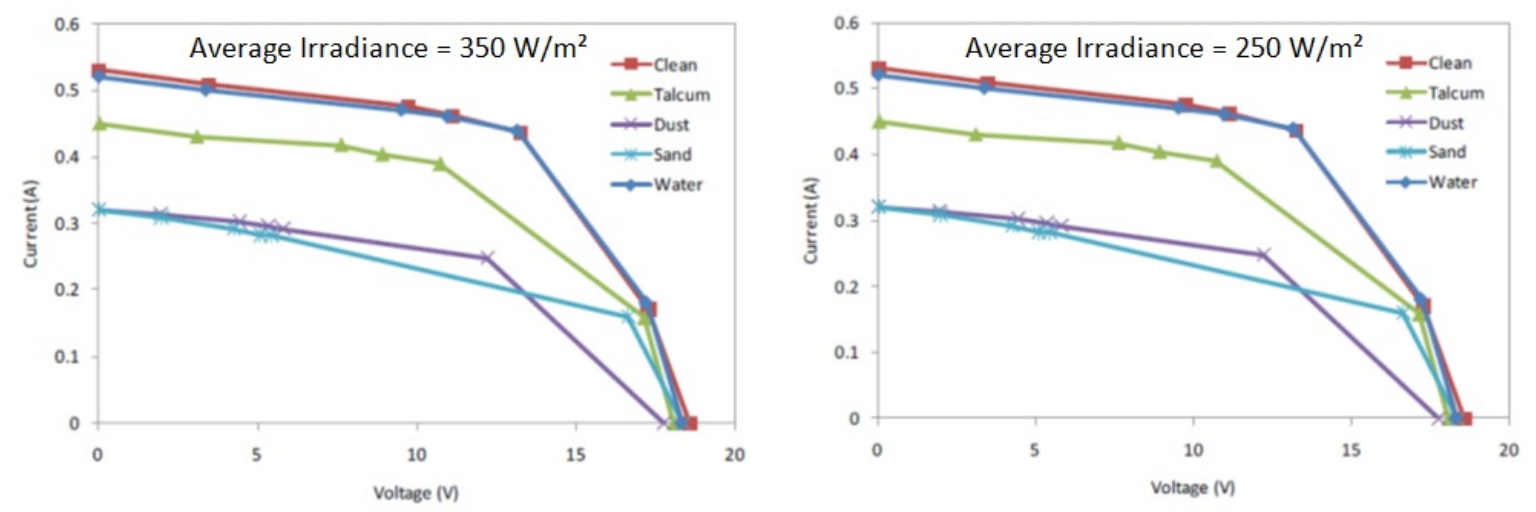

Figure 12. I-V curve for dirt's influence test at radiation intensity of $350 \mathrm{~W} / \mathrm{m}^{2}$ and $250 \mathrm{~W} / \mathrm{m}^{2}$ [10]

Table 2. Comparison of the obtained result (the reduction of $V_{o c}$ and $I_{s c}$ )

\begin{tabular}{|c|c|c|c|c|}
\hline Comparison & Sulaiman et al 201 & & \multicolumn{2}{|c|}{ This Study } \\
\hline Soiling type & $\begin{array}{ll}\text { Talcum } \\
\end{array}$ & & \multirow{2}{*}{\multicolumn{2}{|c|}{$\begin{array}{l}\text { Wheat flour } \\
\text { Artificial soiling spread evenly on the module surface } \\
\text { Loading was measured in } \mathrm{g} / \mathrm{m}^{2} \text { and being increase from } 0 \\
\text { to } 200 \text { with } 10 \mathrm{~g} / \mathrm{m}^{2} \text { increment }\end{array}$}} \\
\hline Methods & Artificial soiling spread evenly on & surface & & \\
\hline $\begin{array}{c}\text { External } \\
\text { Disturbance }\end{array}$ & \multicolumn{2}{|l|}{ Not mentioned } & \multicolumn{2}{|c|}{ Heat from spotlight } \\
\hline$V_{o c}$ reduction & $\begin{array}{l}\text { Average irradiance of } 250 \mathrm{~W} / \mathrm{m}^{2} \\
\text { Average irradiance of } 350 \mathrm{~W} / \mathrm{m}^{2}\end{array}$ & $\begin{array}{l}2.24 \% \\
2.91 \%\end{array}$ & \multirow{2}{*}{$\begin{array}{c}\text { Average irradiance of } \\
396.2222 \mathrm{~W} / \mathrm{m}^{2}\end{array}$} & $0-20.01 \%$ \\
\hline$I_{s c}$ reduction & $\begin{array}{l}\text { Average irradiance of } 250 \mathrm{~W} / \mathrm{m}^{2} \\
\text { Average irradiance of } 350 \mathrm{~W} / \mathrm{m}^{2}\end{array}$ & $\begin{array}{l}13.46 \% \\
18.31 \%\end{array}$ & & $0-20.12 \%$ \\
\hline
\end{tabular}

The results in numerical value are totally different for the both study as the method employ is quite different even with the similar soiling type. Since the average irradiance used in this study is $396.2222 \mathrm{~W} / \mathrm{m}^{2}$, the nearest matching irradiance used by Sulaiman et al which can be made for comparison is at $350 \mathrm{~W} / \mathrm{m}^{2}$. At $200 \mathrm{~g} / \mathrm{m}^{2}$ of wheat flour loading density, the reduction of $V_{o c}$ and $I_{s c}$ due to soiling are $20.01 \%$ and $20.12 \%$ each while from Sulaiman et al are about $2.91 \%$ and $18.31 \%$ each. The reduction of $I_{s c}$ for both study are quite similar, perhaps of the approximated soiling density loaded on the module surface and $I_{s c}$ is fundamentally less affected by module heating. However, for $V_{o c}$ the big different amount of variation for both studies was contributed from module heating. With the module surface distance only $65 \mathrm{~cm}$ from the spotlight, the excessive heat can be absorbed directly even though it was lighten up in a few seconds due to the large spotlight power rating. Theoretically, with the increment of module temperature from $25^{\circ} \mathrm{C}, V_{o c}$ will decrease drastically. Sulaiman et al result can be referred in this case, without the disturbance of module heating, $V_{o c}$ is not significantly affected by soiling. Despite of this, from Table 2, it is seen that with the rising of irradiance level, the reduction of $V_{o c}$ and $I_{s c}$ become more obvious. At the average irradiance of $350 \mathrm{~W} / \mathrm{m}^{2}$ in Sulaiman et al experiment, $V_{o c}$ and $I_{s c}$ was reduce around $2.91 \%$ and $18.31 \%$ each.

\section{CONCLUSIONS}

From the methods employed in this study and comparison made with Sulaiman et al study, it is found that the effect of dust defined by soiling term can truly degrade the performance of a PV system. Below are several conclusions can be made:

I. Impact of soiling on PV system's performance may differ from place to place due to the different geographical condition. It is best described as site specific result.

II. It might be a challenge to study the impact of soiling on PV system's performance in Malaysian climate because there are always natural influence that may cause the fluctuation of solar irradiance such as cloud formation and the rapid changing turn of hot and humid condition. These make the data obtained from outdoor PV system's performance monitoring becoming less accurate and less reliable.

III. Soiling can affect the degradation of PV module output current significantly but less affecting the output voltage.

IV. At higher irradiance level, the effect of soiling on PV system's performance becomes more obvious for silicon type of module. 
V. The other conditions from the nature such as the irradiation heat will definitely worsen the soiling effect on PV system's performance.

\section{ACKNOWLEDGEMENTS}

The authors would like to express their appreciation for the support of Malaysian Ministry of Higher Education and Centre of Electrical Energy Systems (CEES) of Universiti Teknologi Malaysia through the funding from Research University Grant (GUP) Q.J130000.2509.07H54.

\section{REFERENCES}

[1] Kumar, V.N., Design of Solar PV Cell Based Inverter for Unbalanced and Distorted Industrial Loads. Indonesian Journal of Electrical Engineering and Informatics (IJEEI), 2015. 3(2).

[2] Mani, M. and R. Pillai, Impact of dust on solar photovoltaic (PV) performance: research status, challenges and recommendations. Renewable and Sustainable Energy Reviews, 2010. 14(9): p. 3124-3131.

[3] Mekhilef, S., R. Saidur, and M. Kamalisarvestani, Effect of dust, humidity and air velocity on efficiency of photovoltaic cells. Renewable and Sustainable Energy Reviews, 2012. 16(5): p. 2920-2925.

[4] Massi Pavan, A., A. Mellit, and D. De Pieri, The effect of soiling on energy production for large-scale photovoltaic plants. Solar Energy, 2011. 85(5): p. 1128-1136.

[5] Kalogirou, S.A., R. Agathokleous, and G. Panayiotou, On-site PV characterization and the effect of soiling on their performance. Energy, 2013. 51: p. 439-446.

[6] Zorrilla-Casanova, J., et al. Analysis of dust losses in photovoltaic modules. in World Renewable Energy CongressSweden. 2011.

[7] Darwish, Z.A., et al., Effect of dust pollutant type on photovoltaic performance. Renewable and Sustainable Energy Reviews, 2015. 41: p. 735-744.

[8] Elnozahy, A., et al., Performance of a PV module integrated with standalone building in hot arid areas as enhanced by surface cooling and cleaning. Energy and Buildings, 2015. 88: p. 100-109.

[9] Haillant, O., Accelerated weathering testing principles to estimate the service life of organic PV modules. Solar Energy Materials and Solar Cells, 2011. 95(5): p. 1284-1292.

[10] Sulaiman, S.A., et al., Influence of Dirt Accumulation on Performance of PV Panels. Energy Procedia, 2014. 50: p. 50-56.

[11] Cabanillas, R. and H. Munguía, Dust accumulation effect on efficiency of Si photovoltaic modules. Journal of Renewable and Sustainable Energy, 2011. 3(4): p. 043114.

[12] Nagapan, S., I.A. Rahman, and A. Asmi, Factors Contributing to Physical and Non-Physical Waste Generation in Construction Industry. International Journal of Advances in Applied Sciences, 2012. 1(1): p. 1-10.

[13] Fujiwara, F., et al., Spatial and chemical patterns of size fractionated road dust collected in a megacitiy. Atmospheric Environment, 2011. 45(8): p. 1497-1505.

[14] Park, Y.-B., et al., Self-cleaning effect of highly water-repellent microshell structures for solar cell applications. Journal of Materials Chemistry, 2011. 21(3): p. 633-636.

[15] Son, J., et al., A practical superhydrophilic self cleaning and antireflective surface for outdoor photovoltaic applications. Solar Energy Materials and Solar Cells, 2012. 98: p. 46-51.

[16] Cano, J., et al. Effect of tilt angle on soiling of photovoltaic modules. in Photovoltaic Specialist Conference (PVSC), 2014 IEEE 40th. 2014. IEEE.

[17] Jiang, H., L. Lu, and K. Sun, Experimental investigation of the impact of airborne dust deposition on the performance of solar photovoltaic (PV) modules. Atmospheric Environment, 2011. 45(25): p. 4299-4304.

[18] Schill, C., S. Brachmann, and M. Koehl, Impact of soiling on IV-curves and efficiency of PV-modules. Solar Energy, 2015. 112: p. 259-262.

[19] Appels, R., et al., Effect of soiling on photovoltaic modules. Solar Energy, 2013. 96: p. 283-291.

[20] Smith, M.K., et al., Effects of Natural and Manual Cleaning on Photovoltaic Output. Journal of Solar Energy Engineering, 2013. 135(3): p. 034505.

[21] Adinoyi, M.J. and S.A. Said, Effect of dust accumulation on the power outputs of solar photovoltaic modules. Renewable Energy, 2013. 60: p. 633-636.

[22] SIDI, C.E.B.E., et al., Outdoor performance analysis of a monocrystalline photovoltaic module: Irradiance and temperature effect on exergetic efficiency. International Journal of Physical Sciences, 2015. 10(11): p. 351-358.

[23] Konjare, S.S., et al. Efficiency improvement of PV module by way of effective cooling-a review. in Industrial Instrumentation and Control (ICIC), 2015 International Conference on. 2015. IEEE.

[24] Ketjoy, N. and M. Konyu, Study of Dust Effect on Photovoltaic Module for Photovoltaic Power Plant. Energy Procedia, 2014. 52: p. 431-437.

[25] Kazem, A.A., M.T. Chaichan, and H.A. Kazem, Dust effect on photovoltaic utilization in Iraq: Review article. Renewable and Sustainable Energy Reviews, 2014. 37: p. 734-749.

[26] Semaoui, S., et al. Sand Effect on Photovoltaic Array Efficiency in Algerian Desert. in 2nd International Congress on Energy Efficiency and Energy Related Materials (ENEFM2014). 2015. Springer. 


\section{BIOGRAPHIES OF AUTHORS}

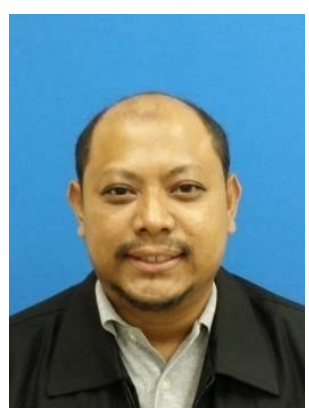

Wan Juzaili bin Jamil is a student, working and pursuing his second Master study under Centre of Electrical Energy Systems (CEES), Universiti Teknologi Malaysia (UTM). He obtained his B.Eng. in Electrical Engineering from UTM in 2007 and Master in Occupational Safety \& Health Management from the same institute in 2013. His research interests are in renewable energy, PV system performance monitoring, soiling impact on PV module and occupational safety \& health management.

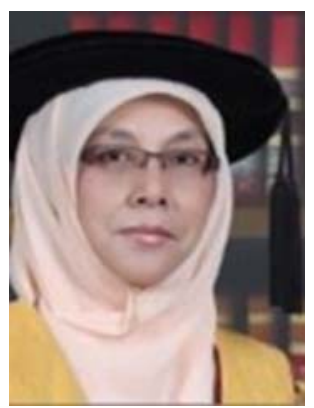

Dr Hasimah Abdul Rahman is an Assoc. Prof. at Faculty of Electrical Engineering and also the Deputy Director of Centre of Electrical Energy Systems (CEES), Universiti Teknologi Malaysia (UTM). She obtained her B.Sc. in Electrical and Electronic Engineering from University of Aberdeen, United Kingdom in 1988, MSc in Energy Studies from University of Wales, College of Cardiff in 1995 and $\mathrm{PhD}$ in Electrical Engineering from UniversitiTeknologi Malaysia in 2012. She has more than 20 years of experience in teaching electrical engineering courses and supervision of more than 60 undergraduates and 6 post graduates students. She has authored and co-authored for more than 30 journal and conference papers. Besides, she was involved in Solar Decathlon China 2013 competition in designing UTM-Solar House. She is a member of Institute Electrical Electronic Engineer (MIEEE). Registered Graduate Member of Institution of Engineers Malaysia (IEM). She holds a Certificate in. Grid-PV (ISPQ-SEDA, Malaysia). Her research interest includes renewable energy technology, energy efficiency, demand side management and its environmental impact. Her specialize area of research is on solar photovoltaic.

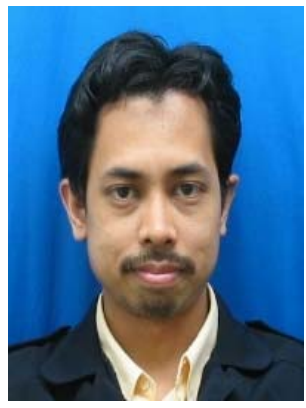

Kyairul Azmi bin Baharin is a PhD candidate working under CEES, UTM. His research interests are grid-connected PV performance and solar energy forecasting. 